\title{
Ancient Numismatics
}

\section{Ulla Westermark}

\begin{abstract}
The author surveys major works, articles and reports dealing with Greek and Roman numismatics and published by Scandinavian scholars within the period 1986-1990.

Ulla Westermark, The Svensson Foundation, Banérgatan 17, S-115 25 Stockholm, Sweden.
\end{abstract}

In Current Swedish Archaeology 1 (1993) Leif Gren gives a lucid account of the Sisyphean tasks of archaeology, the first being the never-ending documentation of objects. Like archaeology, ancient numismatics is faced with an ever increasing source material. Coins are preserved in a greater amount than any other group of items from the Greek and Roman Antiquity, with the exception of potsherds and suchlike. In spite of that the source material is unevenly distributed and is often scarce for a certain mint or period. A special difficulty is that the major part of new material comes from clandestine finds which are immediately dispersed after their discovery and which thus lack all necessary information, even as to their findspots. The existing ancient coins are scattered all over the world in public and private collections, only partly published, and are to a large part accessible only in auction-sale catalogues. To collect all available source material for a mint or a period and arrange it into a corpus is therefore an enormous task. One compensation for the author is, however, that such a study is bound to increase the interest in a certain area. The publication of Georges Le Rider's magistral work Le monnayage d'or et d'argent de Philippe II (1977) focused attention on the Thrako-Macedonian area. Recently a new culmen was reached with the publication of The Coinage in the Name of Alexander the Great and Philip Arrhidaeus (1991) by Martin Price, the first comprehensive study of that immense coinage. The less famous, earlier Macedonian kings have also been the object of renewed studies. An article by U. Westermark (1989a) concentrates on the at first scanty but rapidly increasing bronze coinages of the Macedonian kings, from Archelaos to Perdikkas III. In another article dealing with Macedonian bronze coin series Westermark (1987) argues that there is a common system of weights and denominations shared by the city coins and the regal issues. One of the most important coinages in northern Greece is that of the Chalcidian League, consisting mainly of silver tetradrachms of a high artistic quality. The current chronology established by Robinson and Clement in their corpus of 1938 is founded on the assumption that the coinage was begun immediately after the foundation of the Chalcidian state in $432 \mathrm{BC}$. Finding support in a work by M. Zahrnt (Olynth und die Chalkidier, Vestigia 14, 1971) who distinguishes between an early state centered round Olynthos and a later federal league, Westermark (1988) argues for a lowering of the chronology to the fourth century, which, in her opinion, is in better accordance with the general aspect of the coinage in relation to other mints in the vicinity and not least to the silver and gold coinages of Philip II.

A beautiful new acquisition to the Royal Coin Cabinet in Stockholm from Aigai in Aiolis, a donation from the Svensson Foundation, gave Westermark (1989) the 
opportunity to deal with the short-lived output of wreathed tetradrachms in the style of the period from that small city, obviously covering only a few years around the mid second century BC. Other important gifts of ancient coins to the Royal Coin Cabinet by the Svensson Foundation have been described by Westermark in Svensk Numismatisk Tidskrift (No 9/10, 1986; No 3,1988; No 4/5, 1989; No 7,1989).

The hoards of Roman denarii found north of the limes form a rather homogeneous material; the majority of the coins belong to the period AD 54-200. L. Lind's thesis Romerska denarer funna i Sverige is an analysis of the material compiled in his earlier published catalogue of the Swedish hoards, comprising some 5400 preserved coins out of a total number of c 7000 . Lind's work is the first to be based on a proper catalogue of the rich material. With this time-consuming but necessary cataloging he has laid firm ground for further studies of the internationally important hoard material, which is sure to attract much attention in the future too. Finding that the Gotlandic hoards are strikingly similar in composition and wear to those from Bornholm, Poland and Russia, Lind concludes that they emanate from a common source - an enormous amount of silver gathered by the Germanic peoples of the Vistula area. He makes a strong attempt to find a historical explanation for the outflow of denarii from the Roman Empire and suggests that the silver was paid out by the Romans after AD 200 with the aim of buying peace and preventing the people in the north from joining the Goths, who attacked Rome from the 240 s onwards.

A different interpretation is given by Svend Nielsen (1987-88) in a study of the Roman denarii found in graves in Denmark. Nielsen discusses many aspects, such as the chronological position of the denarii in Denmark and their role in the Iron Age economy in relation to the economic situa- tion in continental Europe. Contrary to Lind, who places the outflow from Rome after AD 200, Nielsen stresses the point that all denarii struck before the devaluation in 194/95 must have left Roman territory before that date, as, due to their higher silver content, they would have gone out of circulation very rapidly within the Empire.

Another Danish contribution, by Kjeld Grinder Hansen (1987-88), also deals with the finds of Roman coins in Scandinavia and is of great general interest. He discusses methodological questions with reference to site-finds of denarii as a source of the much debated Roman economic history. He points out that the existing quantitative models for the examination of coin distribution are often impossible to use when confronted with reality, as there is a severe lack of well-published site-finds from archaeological excavations, giving all necessary information.

Thanks to the project for renewed investigations of archaeological sites on Gotland, headed by RAGU (the Gotland Board of the Central Office of National Antiquities) and carried out by Majvor Östergren, a surprisingly high number of new denarii have been discovered on Gotland since the project started in 1977. Östergren (1989) describes the sites and find circumstances of the four largest hoards, or parts of hoards, found in the 1980s in the parishes of Bäl (1983-84, 40 coins), Garda (1983, 106 coins), Grötlingbo (1983-85, 210 coins) and $\mathrm{Hej-}$ num (1981, 12 coins). New hoards and single finds of Roman and Byzantine coins in Sweden are continuously published in Nordisk Numismatisk Årsskrift (NNÅ). 345 denarii and five solidi, all from Gotland, one antoninianus and one bronze coin of Nero are catalogued in $N N \AA$ 1985-86; 31 more denarii and a late Roman bronze coin of Constantius II, all from Gotland, are reported in $N N \AA$ 1987-88. This latter coin is as such very common, but rare in the present context as it is the only late Roman bronze 
coin hitherto found on Gotland. The coin along with others is included in WestermarkWiséhn's third report on Roman bronze coins found in Sweden (1989). The collected material is yet too scanty to allow any conclusions to be drawn, but it is evident that bronze coins have come in larger quantities than is revealed by the preserved material, as such coins had never been properly taken care of. The bronze coins always seem to be separate from the denarii, but are sometimes mixed with the much debased antoniniani of the third century AD.

One of the main results of Lind's above mentioned thesis (1988) is that he could show beyond doubt that the Swedish denarii hoards are part of larger hoards formed on the Continent. In a similar manner, the solidi found in Sweden and Denmark, emanate from hoards established on the Continent and then dispersed. This has been ably demonstrated by Ola Kyhlberg (1986) in his important, extensive investigation of the solidi finds, an analysis using both quantitative and numerical-typological elements. Departing from Fagerlie's fundamental work (1967), to which he acknowledges his debt, Kyhlberg discusses many aspects of the material. The numismatic results are considerable. Among other things, his method enables him to limit the deposit dates within the three relevant areas as follows: Öland 473-501, Bornholm 488-527 and Gotland 510-588.

English revised by Laura Wrang.

\section{REFERENCES}

Grinder-Hansen, K. 1987-88. Site-finds as a source to the economic history of the Roman Empire. Some methodological problems. Nordisk Numismatisk Ärsskrift, 122-145.

Kyhlberg, O. 1986. Late Roman and Byzantine Solidi. An archaeological analysis of coins and hoards. Excavations at Helg $\ddot{0} \mathrm{X}, 13-126$.

Lind, L. 1988. Romerska denarer funna i Sverige, part 1. The catalogue Roman denarii found in Sweden 2 was published in 1981.

Nielsen, S. 1987-88. Roman Denarii in Denmark - an Archaeological Approach. Nordisk $\mathrm{Nu}_{\text {- }}$ mismatisk Årsskrift, 147-169.

Nordisk Numismatisk Arsskrift 1985-1986. The Royal Coin Cabinet, Stockholm, 1984-1985: 134, 136, 155, 156, 158-159, 168, 170.

Nordisk Numismatisk Arsskrift 1987-1988. The Royal Coin Cabinet, Stockholm, 1986-1987: 190-91,194,203

Westermark,U.1986-1989. Svensk Numismatisk Tidskrift, No 9/10, 1986, 264-66; No 3, 1988, 54-56; No 4/5, 1989, 100-02; No
$7,1989,160-62$

- 1987. Notes on Macedonian Bronze Coins. Studi per Laura Breglia suppl. del Bollettino di $\mathrm{Nu}$ mismatika 4, parte 1, 179-187.

- 1988. The Coinage of the Chalcidian League reconsidered. Studies in Ancient History and Numismatics presented to Rudi Thomsen. Aarhus, 91-103.

- 1989a. Remarks on the Regal Macedonian Coinage ca 413-359 B.C. Kraay-Morkholm Essays. Numismatica Lovaniensis 10. Louvaine-la-Neuve, 301-315.

- 1989b. En tetradrachm från Aigai i Aiolis. Llt. Festskrift till Lars O. Lagerqvist, (Numismatiska Meddelanden 37) 471-475.

Westermark, U. \& Wiséhn, I. 1989. Romerska bronsmynt funna i Sverige 3. Nordisk Numismatisk Unions Medlemsblad 9, 205-209.

Östergren, M. 1989. Nya fynd av romerska denarer på Gotland. Llt. Festskrift till Lar's $O$. Lagerqvist (Numismatiska Meddelanden 37) 511-515. 
